\title{
Pediatric acute respiratory distress syndrome - current views (Review)
}

\author{
JINFENG LIU, WEI WANG, FENGLI LIU and ZHENGUANG LI \\ Department of Neonatology, Xuzhou Chlidren's Hospital, Xuzhou, Jiangsu 221002, P.R. China
}

Received July 28, 2017; Accepted November 29, 2017

DOI: $10.3892 /$ etm.2017.5628

\begin{abstract}
Acute respiratory distress syndrome (ARDS) mainly involves acute respiratory failure. In addition to this affected patients feel progressive arterial hypoxemia, dyspnea, and a marked increase in the work of breathing. The only clinical solution for the above pathological state is ventilation. Mechanical ventilation is necessary to support life in ARDs but it itself worsen lung injury and the term is known clinically as 'ventilation induced lung injury' (VILI). At the cellular level, respiratory epithelial cells are subjected to cyclic stretch, i.e. repeated cycles of positive and negative strain, during normal tidal ventilation. In aerated areas of diseased lungs, or even normal lungs subjected to injurious positive pressure mechanical ventilation, the cells are at risk of being over distended, and worsening injury by disrupting the alveolar epithelial barrier. Further, hypercapnic acidosis (HCA) in itself confers protection from stretch injury, potentially via a mechanisms involving inhibition of nuclear factor $\kappa \mathrm{B}(\mathrm{NF}-\kappa \mathrm{B})$, a transcription factor central to inflammation, injury and repair. Mesenchymal stem cells are the latest in the field and are being investigated as a possible therapy for ARDS.
\end{abstract}

\section{Contents}

1. Introduction

2. Mechanical ventilation role

3. Role in sustaining life in ARDS patients

4. Ventilator-induced lung injury (VILI)

5. Mechanisms of VILI

6. Ventilator-induced lung inflammation

7. Cyclic stretch and transcriptional activation

8. NF- $\kappa \mathrm{B}$ in injury

9. Mechanisms of protection by low tidal volume ventilation

10. Impact of lung ventilatory strategies over time

Correspondence to: Dr Zhenguang Li, Department of Neonatology, Xuzhou Children's Hospital, 18 Sudibei Road, Xuzhou, Jiangsu 221002, P.R. China

E-mail: zhenguangli29@163.com

Key words: ARDS, pediatric, infants, ventilation, lungs, injury
11. The role of carbon dioxide in modulating lung injury

12. Rationale for 'permissive' hypercapnia to reduce lung stretch

13. Therapeutic hypercapnia - further reducing lung injury?

14. Mechanisms of action of HCA

15. HCA and lung

16. MSCs and lung injury

17. Conclusions

\section{Introduction}

Significant morbidity and mortality has been confirmed due to acute respiratory distress syndrome (ARDS) worldwide (1). It is characterized by severe inflammation of the lung parenchyma with associated protein-rich pulmonary oedema leading to hypoxaemia refractory to supplemental oxygen, and respiratory failure (2). Most patients require mechanical ventilation $(\mathrm{MeV})$ as a life-saving measure in an intensive care setting. Many patients frequently develop subsequent multi-organ failure (3). The mortality burden of ARDS approaches that of breast cancer and HIV (4), and could be as high as $60 \%$. There is currently no known treatment, and management remains supportive.

\section{Mechanical ventilation role}

Mechanical ventilation has been the mainstay of life-supporting treatment in intensive care medicine (5). One of the first mechanical ventilators was in the form of an iron lung and a metal cylinder (5). Negative pressure applied in the chamber using a vacuum pump, was used to expand the chest. However, this mode is a difficult procedure with significant discomfort to the patient involved.

The modern positive pressure ventilators reduced mortality from 85 to $20 \%$ (6). In positive pressure ventilation, the airway pressure is applied at the patient's airway via an endotracheal or tracheostomy tube. This permits gas flow into the lungs until the end of the 'breath' delivered by the machine. Elastic recoil of the chest occurs when the airway pressure is zero, leading to passive exhalation.

\section{Role in sustaining life in ARDS patients}

Mechanical ventilation is crucial for patients with ARDS and other forms of respiratory failure (7). Traditionally, most 
patients, including those with ARDS that required mechanical ventilation were ventilated with tidal volumes of more than $9 \mathrm{ml} / \mathrm{kg}$. This in turn helped in maintenance of normal oxygen and carbon dioxide levels along with minimal atelectasis $(8,9)$. To achieve these goals, grossly high peak inspiratory pressures of up to $50 \mathrm{~cm} \mathrm{H}_{2} \mathrm{O}$ were tolerated quite often in the absence of obvious complications of barotrauma, such as the development of pneumothoraces.

\section{Ventilator-induced lung injury (VILI)}

It was discovered that ventilating rat lungs with peak pressures of up to $45 \mathrm{~cm} \mathrm{H}_{2} \mathrm{O}$ resulted in faster onset and more severe pulmonary oedema than when ventilating at pressures of $30 \mathrm{~cm} \mathrm{H}_{2} \mathrm{O}$, and that positive end-expiratory pressure (PEEP) could alleviate that damage (10). VILI can cause or worsen ARDS, and is in fact, a form of ARDS both clinically and pathologically. Animal lungs injured by mechanical ventilation show patterns of atelectasis, severe congestion and enlargement due to oedema. Contemporary ventilation strategies entail use of lower tidal volumes $(6-8 \mathrm{ml} / \mathrm{kg})$ leading to minimal lung over-distension and further injury. ARDS typically does not have a uniform distribution, and affects some segments of lung more severely than others. CT-guided studies have demonstrated particular segments of lung with relatively normal elastance (baby lung) (11,12). Therefore even 'normal' tidal volumes during mechanical ventilation could damage these smaller segments of aerated lung tissue. The Vt/baby lung ratio is more relevant than the $\mathrm{Vt} / \mathrm{kg}$ ratio for VILI in this context.

\section{Mechanisms of VILI}

It was later appreciated that simple barotraumas, i.e. gross air leaks induced by large trans-pulmonary pressures, was not the only way that ventilators could damage lungs. Important mechanistic insights have emerged from extensive research to elucidate the potential mechanisms by which certain ventilator settings may cause specific biological damage. The concept of volutrauma is of the view that lung distention is the cause behind lung injury (13). Atelectrauma is a term used to describe repeated opening and reopening of atelectatic areas leading to high shear stress and subsequent necrosis, classically with high ventilator distending pressures and no PEEP (14). Biotrauma, a relatively recent concept, states that excessive release of proinflammatory mediators and immune system hyperstimulation is the primary mechanism by which injurious ventilation damages the lungs (15).

\section{Ventilator-induced lung inflammation}

Multiple animal models of VILI have demonstrated that injurious ventilation in the form of volutrauma or atelectrauma results in significant leukocyte sequestration and lung damage (16). Cytokines are an important group of mediators in this process. These are low-molecular-weight glycoproteins, produced by a number of cells, which communicate with cell-surface receptors to activate or inhibit the inflammatory cascade. Pro-inflammatory cytokines play an important role in immune cell recruitment and in the activation of macro- phages and polymorphonuclear cells. Mechanical ventilation has the ability to release cytokines in lung cells by a number of mechanisms:

i) Mechanotransduction: the conversion of physical forces on the cell membrane/receptors into promotion of intracellular signal transduction pathways leading to increased synthesis and secretion of cytokines (17). ii) Cell necrosis may result from injurious stretch, leading to secretion of preformed cytokines, which then modulate the production of more cytokines (18). iii) Vascular endothelial cells may exert an increased inflammatory response as a consequence of increased pressure in the pulmonary vasculature by MV (19).

The localized inflammatory response resulting from these mechanisms could rapidly become systemic if the endothelial-epithelial barrier is disrupted secondary to necrosis, permitting 'spillover' of cytokines, endotoxins and bacteria to spread from alveoli into the systemic circulation. Previous studies have linked the systemic inflammatory response that accompanies aggressive mechanical ventilation with cytokine release from lung cells (20), and consequent translocation of cytokines into the bloodstream (21). This loss of pulmonary containment of inflammation, termed de-compartmentalization, explains the high mortality of patients with ARDS from multi-organ failure. This concept of a systemic effect from an initial lung injury is supported by direct evidence from ex vivo studies (22), in vivo animal studies (23) and indirect supportive data from human studies (24). It was observed in an earlier study that high tidal volumes and zero PEEP caused significant elevation in serum levels of $\mathrm{TNF}-\alpha$ compared to rats ventilated at low tidal volumes with or without PEEP and high tidal volumes with PEEP (25). Of note, PEEP is shown to be protective here, as in the high tidal volume group with PEEP, there was no TNF- $\alpha$ response.

\section{Cyclic stretch and transcriptional activation}

Mechano-transduction also stimulates gene transcription following mechano-sensing. A growing body of evidence has implicated the mitogen-activated protein kinase (MAPK) pathway as integral in transduction of signals from the mechano-sensory apparatus to the nucleus and driving gene transcription (26). MAPKs are signaling enzymes activated by phosphorylation in response to a range of extracellular stimuli such as cytokines and growth factors (27).

These enzymes are responsible for the transduction of mitogenic and differentiation signals leading to activation of transcription factors (28). ERK1 and 2 are activated by cyclic stretch in alveolar epithelial cells (29), as well as in a variety of other cell types, including cardiac myocytes (30), endothelial cells (31), and vascular smooth muscle cells (32). Many cyclic stretch studies have demonstrated increased alveolar levels of IL-8, which is highly suggestive of increased transcription of this inflammatory cytokine by mechanical stretch (33). Cyclic stretch has also been demonstrated to induce activation of a powerful transcription factor nuclear factor $\kappa \mathrm{B}(\mathrm{NF}-\kappa \mathrm{B})$.

\section{NF-кB in injury}

The NF- $\kappa \mathrm{B}$ helps in harmonization of the inflammatory response. It regulates pro-inflammatory transcriptional 
programs that carry out this response. Its activation leads to the upregulation of adhesion molecules and chemokines in vascular endothelial cells and within the tissue. It is also essential for the production of antimicrobial effector molecules and for the survival of leukocytes in an inflammatory milieu. Although crucial for an intact host defense response, excessive activation of $\mathrm{NF}-\kappa \mathrm{B}$ leads to exaggerated inflammatory injury of lungs and other organs (34). Mechanical stretch activates the $\mathrm{NF}-\kappa \mathrm{B}$ pathway in cardiac myocytes (35), vascular endothelial cells (36) and alveolar epithelial cells (37).

The presence of this transcription factor in the pathogenesis of lung injury has been demonstrated in many experimental studies. Upregulation of $\mathrm{NF}-\kappa \mathrm{B}$ in response to stretch has been demonstrated in many in vitro and ex vivo lung studies (38). Increased activation of NF- $\kappa \mathrm{B}$ occurs in alveolar macrophages in established ARDS (39). Using an isolated perfused lung model, Held et al demonstrated activation of NF- $\kappa \mathrm{B}$ in response to LPS and ventilation with large tidal volumes $(40)$. $N F-\kappa B$ regulation can take place at any point of its activation and postactivation pathway and probably plays a crucial role in the NF- $\mathrm{NB}$-mediated inflammatory cascade. In ARDS for example, Moine et al (41) showed that $N F-\kappa B$ maintained an activated state in spite of increased $\mathrm{I} \kappa \mathrm{B}$ levels and reductions in Bcl-3 levels (another member of the I $\mathrm{B}$ family). This implies that basic aberrations in $\mathrm{NF}-\kappa \mathrm{B}-$ related transcriptional mechanisms are likely central to the generation of the inflammatory cascade, which occurs in patients with sepsis and ARDS.

\section{Mechanisms of protection by low tidal volume ventilation}

Modulation of the inflammatory response. Protective ventilation has actually been shown to reduce the inflammatory response at a molecular level, compared to more traditional ventilation. It was found in a recent report that BAL levels of IL-1 $\beta$, IL-6, IL-8, TNF- $\alpha$, TNF- $\alpha$ SR55, TNF- $\alpha$ sR75, and IL-1ra decreased over time, as did plasma levels of IL-6. This demonstrated that the protective strategy partially attenuated local and systemic inflammation over time. The low stretch/lung rest arm was concomitant with minimal apoptosis and maximum risks of atelectasis. A study in the recent past noted a significant decrease in interleukin-6 and -8 levels (42). Another study demonstrated reversal of the injurious stretchinduced systemic inflammatory response, in terms of cytokine release, within $6 \mathrm{~h}$ of changing to a protective ventilation strategy, but no impact on the local pulmonary response (43). More recently, a study noted significant reduction in the levels of systemic inflammatory cytokines in the low tidal volume group.

\section{Impact of lung ventilatory strategies over time}

Mortality in ARDS has undoubtedly decreased over time according to a number of studies (44). Protective ventilation has played a major role in this reduction, but other advancements in critical care, such as better supportive care, have been influential. Petrucci and De Feo conducted an extensive metaanalysis in the form of a Cochrane review, which they updated for the third time in 2013 (45) in which they examine all trials to date that have studied the impact of lung protective venti- lator strategies in ARDS. In this most recent update, the main conclusion was the utilization of lower tidal volume ventilation reduces relative risk of death. However, there is scarcity of information regarding conclusion in terms of morbidity and long-term outcomes.

\section{The role of carbon dioxide in modulating lung injury}

Injurious effects of hypocapnia. In contrast, traditional approaches to mechanical ventilation frequently resulted in hypocapnia, which can be severely damaging to lungs. A number of studies in the literature have identified hyperventilation and hypocapnia as risk factors for adverse outcomes in ARDS (46). A possible explanation could be vasoconstriction and hemoglobin oxygen dissociation curve left shift. Both hyperventilation and hypocapnia might be independent causes of bronchopulmonary dysplasia in infants (47). Hypocapnia reduces lung compliance (48), impairs functional surfactant production (49) and increases microvascular permeability in tracheal mucosa (46). Trimble et al, in 1971 demonstrated that hypocapnia increased work of breathing, aggravated ventilation/perfusion mismatch, increased airway resistance, increased the A-a $\mathrm{O}_{2}$ gradient and decreased the $\mathrm{PaO}_{2}$ in patients with ARDS (50). Another study found hypocapnia to be directly deleterious in lung injury, and a promoter of ischemia-reperfusion-induced acute lung injury (51).

\section{Rationale for 'permissive' hypercapnia to reduce lung stretch}

One of the consequences of instituting a low tidal volume ventilatory strategy is a gradually increasing $\mathrm{PCO}_{2}$ level greater than the upper limit of normal, termed hypercapnia. This 'permissive hypercapnia' $\left(\mathrm{PaCO}_{2}>45 \mathrm{mmHg}\right)$ has been adopted as the preferred approach versus normo- or hypocapnic targets in the setting of ALI/ARDS. Having been first demonstrated to be effective in the setting of acute severe asthma (52) in 1984, the strategy was then trialled by Hickling (53) for ARDS in the 1990s. This hypercapnia is accompanied by an acidosis in the acute phase, which is gradually then subjected to renal and tissue buffering. Hickling demonstrated no detrimental effects of this hypercapnic acidosis (HCA) in experimental studies. In subsequent preclinical studies, induced HCA - by means of addition of $\mathrm{CO}_{2}$ to the inspired gases - reduced the severity of acute lung injury (ALI) induced by multiple factors $(54,55)$. HCA has attenuated early lung (56) and systemic (57) sepsis. These preclinical studies have suggested a potential direct benefit of HCA. Moreover, the presence of an HCA at the time of randomization in patients subjected to high tidal volume ventilation was associated with better 28-day survival (58).

\section{Therapeutic hypercapnia - further reducing lung injury?}

Encouraged by the beneficial effects of permissive hypercapnia, some groups hypothesized that deliberately increasing the $\mathrm{PaCO}_{2}$, by either initially ventilating at very low tidal volumes, or by inhalation of small fractions of $\mathrm{CO}_{2}$, would also confer benefit in lung injury - termed 'therapeutic hypercapnia' (TH). Experimental studies exploring this hypothesis have achieved promising results. Laffey and colleagues demonstrated 
a protective effect in an in vivo lung reperfusion injury model (54), while Sinclair et al demonstrated improved lung mechanics, gas exchange and injury scores in rabbits ventilated with high tidal volumes and targeted hypercapnia versus rabbits with eucapnic targets (59). De Smet et al ventilated isolated perfused rat lungs for $2 \mathrm{~h}$ with low $(7 \mathrm{ml} / \mathrm{kg})$ or moderately high $\left(20 \mathrm{ml} / \mathrm{kg}\right.$ ) Vt and $5 \%$ or $20 \% \mathrm{CO}_{2}$, with lipopolysaccharide or saline added to the perfusate (60). HCA resulted in improved pulmonary edema, decreased lung stiffness, and markedly decreased levels of TNF- $\alpha$ and IL- 6 in the lavage and perfusate. Of note, they found HCA to be beneficial, regardless of the tidal volume, suggesting that HCA has independent protective effects. More recent experimental studies have demonstrated that therapeutic hypercapnia improved lung function and reduced inflammation after one-lung ventilation in lobectomy patients (61). Its beneficial effects extend outside the lung to the heart; TH prevents the adverse effects of sustained exposure to iNO on RV systolic function by limiting IL-1-mediated NOS-2 upregulation and consequent nitration (62). Other studies have demonstrated that $\mathrm{TH}$ is neuroprotective via anti-apoptotic mechanisms and improves impaired spatial memory (63). A trial currently in progress will assess the feasibility and safety of targeting mild hypercapnia for $24 \mathrm{~h}$ following intensive care unit admission for cardiac arrest patients. It will also provide insight on whether such treatment improves neurological injury biomarkers concentrations, compared with normocapnia (64). The evidence is mounting in favour of the anti-inflammatory merits of $\mathrm{CO}_{2}$.

\section{Mechanisms of action of HCA}

One therapeutic mechanism is by the attenuation of free radical injury. Laffey and colleagues demonstrated anti-apoptotic effects and inhibition of nitric oxide-derived oxidant generation (65). The study by Takeshita et al provides strong supportive evidence that HCA attenuates LPS-induced NF- $\kappa \mathrm{B}$ activation by suppression of $\mathrm{I} \kappa \mathrm{B} \alpha$ degradation, which in turn leads to downregulation of ICAM-1 and IL-8 in pulmonary endothelial cells (66). Our own group replicated this finding and in addition demonstrated that HCA attenuated ventilation-induced lung injury independent of injury severity in Sprague-Dawley rats and decreased mechanical stretch-induced epithelial injury and death, via an NF- $\kappa$ B-dependent mechanism (67).

\section{HCA and lung}

HCA might also exert potentially deleterious effects in the setting of lung injury and may indeed worsen a pre-existing injury in certain situations. One group demonstrated that HCA worsens protein malfunction by potentiating protein nitration by the free radical, peroxynitrite (68). Other groups, including ours, have shown that HCA impairs bacterial killing in the setting of prolonged lung infection (69), delays plasma membrane resealing, an essential mechanism of cellular repair (70), and inhibits pulmonary epithelial wound healing by decreasing cell migration via an $\mathrm{NF}-\kappa \mathrm{B}$-dependent mechanism (71). Dixon also demonstrated that HCA, along with inhibiting stretch-induced cytokine production, also impaired stretch-induced pulmonary surfactant release in rat alveolar type II cells (72). It can be concluded, therefore, that HCA exerts diverse effects, some of which may be beneficial and others harmful, depending on the context. In this manner, it may constitute a 'double-edged sword'.

\section{MSCs and lung injury}

Mesenchymal stem cells (MSCs) have inbuilt ability of self-renewal and could classically differentiate into mesodermal lineages, including chondrocytes, adipocytes, and osteoblasts (73). There is increasing evidence that they might also differentiate into cells of non-mesodermal origin such as lung epithelial cells (74). MSCs offer unique advantage as they allow allogeneic administration due to their low immunogenicity (75). In this manner, the 'immunomodulatory' properties of adult stem cells like MSCs might be more successful. The alveolar fluid clearance limits and depletion of surfactant are commonly observed in ALI/ARDS (76). In the above situations, MSCs might restore epithelial and endothelial function, either by secretion of paracrine factors to enhance renewal of these tissues or by differentiation into these cell types. ALI/ARDS is also associated with multi-organ failure, which frequently is the reason for mortality in critically ill patients. MSCs have great therapeutic potential in the above cases (77). MSCs have also potential to secrete disease modifying molecules, which might augment their therapeutic effects. As they home to sites of inflammation following intravenous administration after tissue injury (78), MSCs might also act as vector for genetic therapies (79). The intratracheal administration provides access to both the distal lung epithelium and the pulmonary endothelium for stem cell therapies (80). Moreover, MSCs therapeutic potential for ALI/ARDS has been strongly supported (81). However, MSC are still in the early phases of clinical use in the form of various trials. Some trials showed positive effects and favored clinical use (82). These preliminary studies show potential, but larger trials are required for definitive answers.

\section{Conclusions}

To clearly understand the complex interplay between HCA and the NF- $\kappa$ B pathway might allow us to develop more effective strategies to minimize lung injury in ARDS. Generating new insights into the therapeutic potential of MSCs might transform traditional approaches to ARDS management by combining lung repair tactics with attenuation of injury.

\section{References}

1. FesticE,CarrGE,Cartin-CebaR,HindsRF,Banner-GoodspeedV, Bansal V, Asuni AT, Talmor D, Rajagopalan G, Frank RD, et al: Randomized clinical trial of a combination of an inhaled corticosteroid and beta agonist in patients at risk of developing the acute respiratory distress syndrome. Crit Care Med 45: 798-805, 2017.

2. Bime C, Fiero M, Lu Z, Oren E, Berry CE, Parthasarathy S and Garcia JG: High positive end-expiratory pressure is associated with improved survival in obese patients with acute respiratory distress syndrome. Am J Med 130: 207-213, 2017.

3. Kneyber MC: Intraoperative mechanical ventilation for the pediatric patient. Best Pract Res Clin Anaesthesiol 29: 371-379, 2015.

4. Rubenfeld GD: Epidemiology of acute lung injury. Crit Care Med 31 (Suppl 4): S276-S284, 2003.

5. Slutsky AS: History of mechanical ventilation. From Vesalius to Ventilator-induced lung injury. Am J Respir Crit Care Med 191: 1106-1115, 2015. 
6. Nilsson K, Ekström-Jodal B, Meretoja O, Valentin N and Wagner K: The development of pediatric anesthesia and intensive care in Scandinavia. Paediatr Anaesth 25: 453-459, 2015.

7. Brower RG, Matthay MA, Morris A, Schoenfeld D, Thompson BT and Wheeler A; Acute Respiratory Distress Syndrome Network: Ventilation with lower tidal volumes as compared with traditional tidal volumes for acute lung injury and the acute respiratory distress syndrome. N Engl J Med 342: 1301-1308, 2000

8. Sheu CC, Gong MN, Zhai R, Chen F, Bajwa EK, Clardy PF, Gallagher DC, Thompson BT and Christiani DC: Clinical characteristics and outcomes of sepsis-related vs non-sepsis-related ARDS. Chest 38: 559-567, 2010.

9. Schouten M, Wiersinga WJ, Levi M and van der Poll T: Inflammation, endothelium, and coagulation in sepsis. J Leukoc Biol 83: 536-545, 2008 .

10. Webb $\mathrm{HH}$ and Tierney DF: Experimental pulmonary edema due to intermittent positive pressure ventilation with high inflation pressures. Protection by positive end-expiratory pressure. Am Rev Respir Dis 110: 556-565, 1974.

11. Gattinoni L and Pesenti A: The concept of 'baby lung'. Intensive Care Med 31: 776-784, 2005

12. Chiumello D, Carlesso E, Cadringher P, Caironi P, Valenza F, Polli F, Tallarini F, Cozzi P, Cressoni M, Colombo A, et al: Lung stress and strain during mechanical ventilation for acute respiratory distress syndrome. Am J Respir Crit Care Med 178 346-355, 2008

13. Dreyfuss D, Ricard JD and Saumon G: On the physiologic and clinical relevance of lung-borne cytokines during ventilator-induced lung injury. Am J Respir Crit Care Med 167: 1467-1471, 2003.

14. Slutsky AS: Lung injury caused by mechanical ventilation. Chest 116 (Suppl 1): S9-S15, 1999.

15. Slutsky AS: Ventilator-induced lung injury: From barotrauma to biotrauma. Respir Care 50: 646-659, 2005

16. Dreyfuss D and Saumon G: Ventilator-induced lung injury: Lessons from experimental studies. Am J Respir Crit Care Med 157: 294-323, 1998.

17. Taniguchi LU, Caldini EG, Velasco IT and Negri EM: Cytoskeleton and mechanotransduction in the pathophysiology of ventilator-induced lung injury. J Bras Pneumol 36: 363-371, 2010 (In Portuguese).

18. Mourgeon E, Isowa N, Keshavjee S, Zhang X, Slutsky AS and Liu M: Mechanical stretch stimulates macrophage inflammatory protein-2 secretion from fetal rat lung cells. Am J Physiol Lung Cell Mol Physiol 279: L699-L706, 2000.

19. Uhlig S: Ventilation-induced lung injury and mechanotransduction: Stretching it too far? Am J Physiol Lung Cell Mol Physiol 282: L892-L896, 2002

20. Tremblay LN, Miatto D, Hamid Q, Govindarajan A and Slutsky AS: Injurious ventilation induces widespread pulmonary epithelial expression of tumor necrosis factor-alpha and interleukin-6 messenger RNA. Crit Care Med 30: 1693-1700, 2002.

21. Tremblay L, Valenza F, Ribeiro SP, Li J and Slutsky AS Injurious ventilatory strategies increase cytokines and c-fos $\mathrm{m}-\mathrm{RNA}$ expression in an isolated rat lung model. J Clin Invest 99: 944-952, 1997

22. Tutor JD, Mason CM, Dobard E, Beckerman RC, Summer WR and Nelson S: Loss of compartmentalization of alveolar tumor necrosis factor after lung injury. Am J Respir Crit Care Med 149: 1107-1111, 1994

23. Nahum A, Hoyt J, Schmitz L, Moody J, Shapiro R and Marini JJ: Effect of mechanical ventilation strategy on dissemination of intratracheally instilled Escherichia coli in dogs. Crit Care Med 25: 1733-1743, 1997.

24. Ranieri VM, Giunta F, Suter PM and Slutsky AS: Mechanical ventilation as a mediator of multisystem organ failure in acute respiratory distress syndrome. JAMA 284: 43-44, 2000.

25. Chiumello D, Pristine G and Slutsky AS: Mechanical ventilation affects local and systemic cytokines in an animal model of acute respiratory distress syndrome. Am J Respir Crit Care Med 160: 109-116, 1999.

26. Peverali FA, Basdra EK and Papavassiliou AG: Stretch-mediated activation of selective MAPK subtypes and potentiation of AP-1 binding in human osteoblastic cells. Mol Med 7: 68-78, 2001

27. Chang L and Karin M: Mammalian MAP kinase signalling cascades. Nature 410: 37-40, 2001

28. Cobb MH and Goldsmith EJ: How MAP kinases are regulated. J Biol Chem 270: 14843-14846, 1995.

29. Correa-Meyer E, Pesce L, Guerrero C and Sznajder JI: Cyclic stretch activates ERK1/2 via G proteins and EGFR in alveolar epithelial cells. Am J Physiol Lung Cell Mol Physiol 282: L883-L891, 2002
30. Yamazaki T, Tobe K, Hoh E, Maemura K, Kaida T, Komuro I, Tamemoto H, Kadowaki T, Nagai R and Yazaki Y: Mechanical loading activates mitogen-activated protein kinase and S6 peptide kinase in cultured rat cardiac myocytes. J Biol Chem 268: 12069-12076, 1993.

31. Traub O and Berk BC: Laminar shear stress: Mechanisms by which endothelial cells transduce an atheroprotective force. Arterioscler Thromb Vasc Biol 18: 677-685, 1998.

32. Xu Q, Liu Y, Gorospe M, Udelsman R and Holbrook NJ: Acute hypertension activates mitogen-activated protein kinases in arterial wall. J Clin Invest 97: 508-514, 1996.

33. Oudin S and Pugin J: Role of MAP kinase activation in interleukin-8 production by human BEAS-2B bronchial epithelial cells submitted to cyclic stretch. Am J Respir Cell Mol Biol 27: 107-114, 2002.

34. Fan J, Kapus A, Li YH, Rizoli S, Marshall JC and Rotstein OD: Priming for enhanced alveolar fibrin deposition after hemorrhagic shock: Role of tumor necrosis factor. Am J Respir Cell Mol Biol 22: 412-421, 2000

35. Crosara-Alberto DP, Inoue RY and Costa CR: FAK signalling mediates NF- kappaB activation by mechanical stress in cardiac myocytes. Clin Chim Acta 403: 81-86, 2009.

36. Zhao H, Hiroi T, Hansen BS and Rade JJ: Cyclic stretch induces cyclooxygenase- 2 gene expression in vascular endothelial cells via activation of nuclear factor kappa-beta. Biochem Biophys Res Commun 389: 599-601, 2009.

37. Davidovich N, DiPaolo BC, Lawrence GG, Chhour P, Yehya N and Margulies SS: Cyclic stretch-induced oxidative stress increases pulmonary alveolar epithelial permeability. Am J Respir Cell Mol Biol 49: 156-164, 2013.

38. Lentsch AB, Czermak BJ, Bless NM, Van Rooijen $\mathrm{N}$ and Ward PA: Essential role of alveolar macrophages in intrapulmonary activation of NF-kappaB. Am J Respir Cell Mol Biol 20: 692-698, 1999

39. Schwartz MD, Moore EE, Moore FA, Shenkar R, Moine P, Haenel JB and Abraham E: Nuclear factor-kappa B is activated in alveolar macrophages from patients with acute respiratory distress syndrome. Crit Care Med 24: 1285-1292, 1996.

40. Held HD, Boettcher S, Hamann L and Uhlig S: Ventilationinduced chemokine and cytokine release is associated with activation of nuclear factor-kappaB and is blocked by steroids. Am J Respir Crit Care Med 163: 711-716, 2001.

41. Moine P, McIntyre R, Schwartz MD, Kaneko D, Shenkar R, Le Tulzo Y, Moore EE and Abraham E: NF-kappaB regulatory mechanisms in alveolar macrophages from patients with acute respiratory distress syndrome. Shock 13: 85-91, 2000.

42. Parsons PE, Eisner MD, Thompson BT, Matthay MA, Ancukiewicz M, Bernard GR and Wheeler AP; NHLBI Acute Respiratory Distress Syndrome Clinical Trials Network: Lower tidal volume ventilation and plasma cytokine markers of inflammation in patients with acute lung injury. Crit Care Med 33: 1-6, discussion 230-232, 2005 .

43. Stüber F, Wrigge H, Schroeder S, Wetegrove S, Zinserling J, Hoeft A and Putensen C: Kinetic and reversibility of mechanical ventilation-associated pulmonary and systemic inflammatory response in patients with acute lung injury. Intensive Care Med 28: 834-841, 2002.

44. Zambon $M$ and Vincent JL: Mortality rates for patients with acute lung injury/ARDS have decreased over time. Chest 133: $1120-1127,2008$

45. Petrucci $\mathrm{N}$ and De Feo C: Lung protective ventilation strategy for the acute respiratory distress syndrome. Cochrane Database Syst Rev 2: CD003844, 2013

46. Reynolds AM, Zadow SP, Scicchitano R and McEvoy RD: Airway hypocapnia increases microvascular leakage in the guinea pig trachea. Am Rev Respir Dis 145: 80-84, 1992.

47. Garland JS, Buck RK, Allred EN and Leviton A: Hypocarbia before surfactant therapy appears to increase bronchopulmonary dysplasia risk in infants with respiratory distress syndrome. Arch Pediatr Adolesc Med 149: 617-622, 1995.

48. Cutillo A, Omboni E, Perondi R and Tana F: Effect of hypocapnia on pulmonary mechanics in normal subjects and in patients with chronic obstructive lung disease. Am Rev Respir Dis 110: 25-33, 1974.

49. Oyarzun MJ, Donoso P and Quijada D: Role of hypocapnia in the alveolar surfactant increase induced by free fatty acid intravenous infusion in the rabbit. Respiration 49: 187-194, 1986.

50. Trimble C, Smith DE, Rosenthal MH and Fosburg RG: Pathophysiologic role of hypocarbia in post-traumatic pulmonary insufficiency. Am J Surg 122: 633-638, 1971. 
51. Laffey JG, Engelberts D and Kavanagh BP: Injurious effects of hypocapnic alkalosis in the isolated lung. Am J Respir Crit Care Med 162: 399-405, 2000.

52. Darioli R and Perret C: Mechanical controlled hypoventilation in status asthmaticus. Am Rev Respir Dis 129: 385-387, 1984.

53. Hickling KG: Ventilatory management of ARDS: Can it affect the outcome? Intensive Care Med 16: 219-226, 1990.

54. Laffey JG, Tanaka M, Engelberts D, Luo X, Yuan S, Tanswell AK, Post M, Lindsay T and Kavanagh BP: Therapeutic hypercapnia reduces pulmonary and systemic injury following in vivo lung reperfusion. Am J Respir Crit Care Med 162: 2287-2294, 2000.

55. Laffey JG, Jankov RP, Engelberts D, Tanswell AK, Post M, Lindsay T, Mullen JB, Romaschin A, Stephens D, McKerlie C, et al: Effects of therapeutic hypercapnia on mesenteric ischemiareperfusion injury. Am J Respir Crit Care Med 168: 1383-1390, 2003.

56. Ni Chonghaile M, Higgins BD, Costello JF and Laffey JG: Hypercapnic acidosis attenuates severe acute bacterial pneumonia-induced lung injury by a neutrophil-independent mechanism. Crit Care Med 36: 3135-3144, 2008.

57. Costello J, Higgins B, Contreras M, Chonghaile MN, Hassett P, O'Toole D and Laffey JG: Hypercapnic acidosis attenuates shock and lung injury in early and prolonged systemic sepsis. Crit Care Med 37: 2412-2420, 2009.

58. Kregenow DA, Rubenfeld GD, Hudson LD and Swenson ER: Hypercapnic acidosis and mortality in acute lung injury. Crit Care Med 34: 1-7, 2006.

59. Sinclair SE, Kregenow DA, Lamm WJ, Starr IR, Chi EY and Hlastala MP: Hypercapnic acidosis is protective in an in vivo model of ventilator-induced lung injury. Am J Respir Crit Care Med 166: 403-408, 2002

60. De Smet HR, Bersten AD, Barr HA and Doyle IR: Hypercapnic acidosis modulates inflammation, lung mechanics, and edema in the isolated perfused lung. J Crit Care 22: 305-313, 2007.

61. Gao W, Liu DD, Li D and Cui GX: Effect of therapeutic hypercapnia on inflammatory responses to one-lung ventilation in lobectomy patients. Anesthesiology 122: 1235-1252, 2015.

62. Dunlop K, Gosal K, Kantores C, Ivanovska J, Dhaliwal R, Desjardins JF, Connelly KA, Jain A, McNamara PJ and Jankov RP: Therapeutic hypercapnia prevents inhaled nitric oxide-induced right- ventricular systolic dysfunction in juvenile rats. Free Radic Biol Med 69: 35-49, 2014.

63. Tao T, Zhao M, Yang W, Bo Y and Li W: Neuroprotective effects of therapeutic hypercapnia on spatial memory and sensorimotor impairment via anti-apoptotic mechanisms after focal cerebral ischemia/reperfusion. Neurosci Lett 573: 1-6, 2014.

64. Eastwood GM, Schneider AG, Suzuki S, Bailey M and Bellomo R; CCC trial investigators: A pilot feasibility, safety and biological efficacy multicentre trial of therapeutic hypercapnia after cardiac arrest: Study protocol for a randomized controlled trial. Trials 16: 135, 2015.

65. Laffey JG, Honan D, Hopkins N, Hyvelin JM, Boylan JF and McLoughlin P: Hypercapnic acidosis attenuates endotoxininduced acute lung injury. Am J Respir Crit Care Med 169: 46-56, 2004.

66. Takeshita K, Suzuki Y, Nishio K, Takeuchi O, Toda K, Kudo H, Miyao N, Ishii M, Sato N, Naoki K, et al: Hypercapnic acidosis attenuates endotoxin-induced nuclear factor-[kappa]B activation. Am J Respir Cell Mol Biol 29: 124-132, 2003.

67. Contreras M, Ansari B, Curley G, Higgins BD, Hassett $P$, O'Toole D and Laffey JG: Hypercapnic acidosis attenuates ventilation-induced lung injury by a nuclear factor- $\chi \mathrm{B}$-dependent mechanism. Crit Care Med 40: 2622-2630, 2012.
68. Lang JD Jr, Chumley P, Eiserich JP, Estevez A, Bamberg T, Adhami A, Crow J and Freeman BA: Hypercapnia induces injury to alveolar epithelial cells via a nitric oxide-dependent pathway. Am J Physiol Lung Cell Mol Physiol 279: L994-L1002, 2000.

69. O'Croinin DF, Nichol AD, Hopkins N, Boylan J, O'Brien S, O'Connor C, Laffey JG and McLoughlin P: Sustained hypercapnic acidosis during pulmonary infection increases bacterial load and worsens lung injury. Crit Care Med 36: 2128-2135, 2008.

70. Doerr CH, Gajic O, Berrios JC, Caples S, Abdel M, Lymp JF and Hubmayr RD: Hypercapnic acidosis impairs plasma membrane wound resealing in ventilator-injured lungs. Am J Respir Crit Care Med 171: 1371-1377, 2005.

71. O'Toole D, Hassett P, Contreras M, Higgins BD, McKeown ST, McAuley DF, O'Brien T and Laffey JG: Hypercapnic acidosis attenuates pulmonary epithelial wound repair by an NF-kappaB dependent mechanism. Thorax 64: 976-982, 2009.

72. Dixon DL, Barr HA, Bersten AD and Doyle IR: Intracellular storage of surfactant and proinflammatory cytokines in co-cultured alveolar epithelium and macrophages in response to increasing $\mathrm{CO}_{2}$ and cyclic cell stretch. Exp Lung Res 34: 37-47, 2008.

73. McCulloch EA and Till JE: Perspectives on the properties of stem cells. Nat Med 11: 1026-1028, 2005.

74. Kotton DN, Ma BY, Cardoso WV, Sanderson EA, Summer RS, Williams MC and Fine A: Bone marrow-derived cells as progenitors of lung alveolar epithelium. Development 128: 5181-5188, 2001.

75. Moodley YP and Lalloo UG: Exhaled nitric oxide is elevated in patients with progressive systemic sclerosis without interstitial lung disease. Chest 119: 1449-1454, 2001.

76. Ware LB and Matthay MA: The acute respiratory distress syndrome. N Engl J Med 342: 1334-1349, 2000.

77. Phinney DG and Prockop DJ: Concise review: mesenchymal stem/multipotent stromal cells: the state of transdifferentiation and modes of tissue repair - current views. Stem Cells 25: 2896-2902, 2007.

78. Chapel A, Bertho JM, Bensidhoum M, Fouillard L, Young RG, Frick J, Demarquay C, Cuvelier F, Mathieu E, Trompier F, et al: Mesenchymal stem cells home to injured tissues when co-infused with hematopoietic cells to treat a radiation-induced multi-organ failure syndrome. J Gene Med 5: 1028-1038, 2003.

79. Mei SH, McCarter SD, Deng Y, Parker CH, Liles WC and Stewart DJ: Prevention of LPS-induced acute lung injury in mice by mesenchymal stem cells overexpressing angiopoietin 1. PLoS Med 4: e269, 2007.

80. MacLoughlin RJ, Higgins BD, Laffey JG and O'Brien T: Optimized aerosol delivery to a mechanically ventilated rodent. J Aerosol Med Pulm Drug Deliv 22: 323-332, 2009.

81. Lee JW, Fang X, Gupta N, Serikov V and Matthay MA: Allogeneic human mesenchymal stem cells for treatment of E. coli endotoxin-induced acute lung injury in the ex vivo perfused human lung. Proc Natl Acad Sci USA 106: 16357-16362, 2009.

82. Wilson JG, Liu KD, Zhuo H, Caballero L, McMillan M, Fang X, Cosgrove K, Vojnik R, Calfee CS, Lee JW, et al: Mesenchymal stem (stromal) cells for treatment of ARDS: A phase 1 clinical trial. Lancet Respir Med 3: 24-32, 2015.

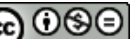

This work is licensed under a Creative Commons Attribution-NonCommercial-NoDerivatives 4.0 International (CC BY-NC-ND 4.0) License. 